\title{
Resume of Marine Geological Investigations Carried Out by the Atlantic Oceanographic Group in the Gulf of St. Lawrence - 1961 - 1964 \\ by DOUGLAS LORING
}

The ATLANTIC OCEANOGRAPHIC GROUP, located at the BEDFORD INSTITUTE OF OCEANOCRAPHY, is a division of the FISHERIES RESEARCH BOARD'S Biological Station, St。 Andrew's, N. B. Under this direction, it conducts research on fundamental problems related to fisheries in the fields of physics, biology, chemistry, and geology。

Early in 1961, a marine geological program was initiated to provide the Board's biologists with detailed information on the physical and chemical characteristics of the surface sediments in the river and Gulf of St. Lawrence as well as regional sedimentary conditions. This program was carried out at sea aboard CNAV SACKVILLE。 This vessel, provided by the ROYAL CANADIAN NAVY for oceanographic purposes, is equipped for taking bottom grab samples, short cores, and has a precision Depth Recorder for making continuous graphic recordings of the submarine topography。

Initial reconnaissance surveys of the River and fulf in 1961 , and in 1962 were mainly confined to sampling the deep submarine trough which is usually referred to as the Laurentian Channel, or the Cabot Strait trough, and has depths of over 200 fathoms. This trough extends from the edge of the continental shelf into the culf of St. Lawrence, and thence into the St. Lawrence estuary as far as the mouth of the Saguenay River. Between the mouth of the Saguenay River and the entrance to the Gulf grab samples of the sediments along with short cores were obtained from 20 cross-sections of the trough. The sampling interval along each cross-section was varied with changes in the bottom topography.

The study of the physical characteristics (1ithology, grain size distribution, and mineralogy) of the sediments obtained during these cruises was undertaken by D.J.G. NOTA of the AGRICULTURE STATE UNIVERSITY, Wageningen, Holland (Visiting Professor of Marine Geology, DALHOUSIE UNIVERSITY, Halifax, NoS。1961-1962)。 The detailed study of the geochemistry of the major elements in the sediments occupying the mouth of the St. Lawrence River (Pte. des Monts to Anticosti Is land) was undertaken by the ATLANTIC OCEANOGRAPHIC GROUP Pre liminary results of these studies (LORINC, 1962; Loring and LAHEY, 1963; Nota and Loring, 1965) show that the sedimentology of the Laurentian Channel is closely related to pleistocene glaciation and present climatic conditions. It was found that the distribution pattern of the sediments in the trough is fairly regular and characterized by poorly sorted coarse grained nearshore deposits and an extensive area of soft pelite bottom in the deeper parts of the trough. Inspection of the echograms taken across the trough shows that the thickness of the soft sedimentary layer, which forms the post-glacial sediment addition, varies strongly regionally and has a maximum thickness of 72 feet. It is believed that erosive conditions in the St. Lawrence River between 
Quebec City and the Saguenay supply a substantial amount of the fine grained material which is being deposited in the trough below the mouth of the Saguenay River at an estimated rate of $22 \mathrm{~cm} / \mathrm{century}$. The mineralogical and geochemical studies of these sediments have indicated that the sediments are mineralogically immature. A study of the composition of the heavy and light mineral fractions in the sediments reveals that the crystallines of the Canadian Shield are the principal sources of the sands.

As well as continuing this work on the laurentian Channel, and in response to FISHERIES RESEAPCH BOARD's requirements, more attention over the past two years is being directed towards studies of the morphology and sedimentology of the Magdalen Shallows. These form the vast submerged plain that occupies the southern embayment of the Gulf of St. Lawrence whose shoreline, a semicircle of about $100 \mathrm{miles}$ radius, extends from Cape North, Cape Breton Island to Cape Gaspe, Quebec.

In 1963 an extensive bottom sampling program was carried out in the central part of the Shallows from prince Edward Island northward to the edge of the Laurentian Channel. In 1964, this sampling program was extended east to the shoreline of Cape Breton Island and west to the shores of New Brunswick and the Gaspe Peninsula, excluding Northumberland Strait, Georges Bay and the Bay of Chaleur. The physical characteristics (lithology, grain size distribution, and mineralogy) of the sediments obtained from the Magdalen Shallows are now under study and preliminary results are expected in the near future. It is upon this information that the ATLANTIC OCEANOGRAPHIC GROUP plans to base its sampling of the ben. thic biological communities in the Magdalen Shallows as well as the regional conditions of sedimentation in this area.

Publications

LORING, Do, 1962, A preliminary study of the soft sediment layer in the Gulf of St. Lawrence and of the Scotian and Newfoundland Shelves: Fish. Res. Board Canada Ms. 107.

LORING, Do, and LAHEY, $\ldots, 1963$, Distribution of calcium carbonate in the sediments of the River. Estuary, and Culf of St. Lawrence: Fish. Res. Board Canada Ms. 140.

NOTA, D,J.G, and LORINC, D., 1965, Recent depositional conditions in the River and rulf of St. Lawrence: Marine Ceology (in press). 